\title{
Cross-Border Cooperation in Europe: A relational perspective
}

Cross-border cooperation, border regions, soft spaces? This special issue approaches cross-border informal planning processes in cross-border regions by analysing them from a perspective that combines networks, governance and territorialisation. Such a relational perspective will be developed by papers which deal with a variety of European cross-border regions and empirical evidence related to the nexus of networks, governance and territorialisation.

Keywords: border, networks, governance, territorialisation

\section{Introduction}

In times when national borders are becoming increasingly hardened due to the upcoming BREXIT, the re-invention of border controls in several countries from the Schengen Area due to the increasing influx of migrants, or the increasing extreme right-wing populism in many European countries that support nationalism, cross-border cooperation (CBC) can be seen as an important tool to overcome these tendencies. But what does this mean? If we examine the terminology used, cross-border cooperation can already be seen quite diffuse and dispersed, varying across different settings. Berzi (2017, p. 1575) states that at least the following terms are common in research as well as in planning and policy documents: 'border zone, borderland, (cross-border) area, (cross-border) region, each term emphasizing the specific aspect, depending on the historical, cultural, political dynamics as well as the geographical conditions.' This explanation nonetheless already shows that we are dealing with quite diverse regions and contexts. Fricke (2015, p. 849) argues that 'Spatial development across national borders is one of the central aims of European political 
integration.' So there needs to be a common ground for all this diversity. Sohn (2014, p. 605) adds that this kind of European integration is based on 'the active involvement of actors mobilizing borders as an economic, political or symbolic resource.' This concept includes strengthening actor networks, having a governance structure, and also the territorialisation of European integration in European internal as well as external border regions. Faludi (2016, p. 78) describes Europe 'as comprising overlapping and intersecting areas, each requiring its own governance $[\ldots]$ as the intersection between various spatial configurations.' This requires new ways of spatial planning - formal as well as informal, but not set according to national borders.

As planning is, however, first of all the sovereign right of each state as manifested in laws, regulations and other legal tools, cross-border cooperation can be seen as a measure to overcome this national setting (at least partly). Borders are also symbols of different power relations between states or actors, which can be carved out also in spatial planning and spatial development (e.g. Newman, 2011; Schulz, 2013).

However, any resulting spatial plan depends on the existence of political and legal institutions for it to be implemented. Sooner or later, planning must deal with this external context, most often a context that is national. When involving various stakeholders in a planning project, much of this context is already known and present in the collective memory. The collaborative process takes places within this shared context. Planning in cross-border regions, on the other hand, involves stakeholders embedded in divergent political, legal, and, more broadly, cultural contexts. In the same way that these contexts are silently acting in the domestic setting, so too will they bear on what stakeholders bring to table in cross-border settings. (Jacobs, 2016, p. 69) 
Cross-border processes need therefore to overcome discontinuities that result from, for example, differences of systems, political cultures or a complex situation of actors involved in the specific conditions and contexts of border regions. Simultaneously, there is enormous potential for the development of innovative approaches in cross-border regions due to the diversity of strategies, initiatives, actors and structures based on differences (e.g. Hillgruber, 2003; Jacobs, 2016; Leibenath, 2008; Schulz, 2013). The study of cross-border regions can thus discuss differences and discontinuities as a specific challenge, but also as opportunities for creative-productive solutions to overcome borders. The border can counterbalance peripheralization and marginalization trends that border regions might experience in their state (e.g. Fricke, 2014). Due to the absence of one responsible planning institution, crossborder spatial planning means that the national, regional and/or local planning institutions of both sides of the border must negotiate the planning process (Durand, 2014; Nienaber, 2018). These either informal or formal planning processes however always need to take the historical, economic, social, political and (spatial) planning context into consideration to overcome planning barriers (Jacobs, 2016).

Building on preliminary pilot $\mathrm{CBC}$, especially in the Dutch-German border regions, had already become a very popular concept in the late 1990s when the European Commission established INTERREG as a common task and later as a mainstream model to promote crossborder regions. The variety of $\mathrm{CBC}$ is now very broad, ranging from informal meetings between actors in the cross-border regions, through different types of formalization and institutionalization, to the European Grouping of Territorial Cooperation (EGTC) as a legal entity. They can vary in terms of their organizational forms, the content-related orientation, their territorial perimeters or the networks, stakeholders and actors involved. 


\section{Networks, governance and territorialisation - a relational perspective}

Social, political, institutional, economic or transport networks can overcome borders or build new borders (e.g. by excluding actors, strategies, cities etc.). There is very often an imbalance of inclusion into broader, maybe even global networks in cross-border regions, so that crossborder networks can (partly) overcome this lack of inclusion. The public-specific approach to network coordination is characterized by (1) the inclusion of the multiplicity of actors of diverse status, objectives and formally autonomous functions but interoperable, (2) the use of differentiated decision-making mechanisms and instruments for their implementation in the network: negotiations, tenders, agreement, rarely unanimity. Network capacity is also crucial for integrating the resources of its participants, serving both the public and individual purposes of network participants and the relatively high network capacity for self-regulation and learning or social innovation (Andersen, Klatt, Sandberg, 2012; Eriksen, 2005; Klijn, Skelcher, 2007). Their construction, relation and management will be seen as a foundation on which to build cross-border governance strategies and to deal with the diversity of crossborder regions. The governance shows the presence or absence of dealing with different planning cultures, instruments and tools and the ability to communicate the knowledge about these across borders. Cross-border governance benefits from a set of common horizontal, participative, consensual and generally low-level hierarchical practices between public and private actors, whose degree of involvement is usually negotiable according to individual will. It is often therefore not a new tool that is needed, but better linkages and knowledge of existing tools and measures. This is also related to the "shift from "government" to "governance"” (Getimis, 2012, p. 25) and also to more upcoming informal ways of spatial planning through new forms of governance. Especially in border regions, these informal governance processes were seen as mean to support the European integration process (Schulz, 2013; Scott, 2005). The main cross-border governance structures are cross-border cooperation 
practices as informal planning instruments. It is therefore especially 'trust' and 'power' that are needed; without these two concepts, governance would not succeed in implementing any networks or development (Hidle and Normann, 2013). The Association of Border Regions (AEBR) (2018) counts 17 large-scale cross-border cooperations, 185 border and cross-border regions and 18 European Groupings of Territorial Cooperation (EGTC). These cooperations overcome on the one hand national borders, while on the other hand giving national borders a symbolic definitional power and bring them greater recognition (Fricke, 2015). There are now top-down and bottom-up approaches (see e.g. Berzi, 2017) which shows that one of the main characteristics of border regions is 'inbetweenness', which can be seen as a resource or as a barrier. The border regions cannot be seen as independent entities, but are located in a multilevel governance system of global developments, European, national, regional and local policies, actors, networks and social, economic, historical and political contexts.

At the same time, the territorialisation shows the bounding of 'soft' (Allmendiger et al., 2015; Haughton et al. 2010) or mobile perimeters of CBC, depending on the networks involved, the governance structure, and also the multiscalarity of CBC. In this sense, Popescu argues that local and regional $\mathrm{CBCs}$ are conceived as a geopolitical process of rescaling that is, in other words, the reorganization of the social, economic and political activity at the sub-national level, transcending the Westphalian system (Popescu, 2008). The participation on regional and local levels in cross-border cooperation agreements might have an impact on EU policymaking since it allows territorial actors to be involved in the realm of international relations, usually dominated by central governments (Börzel, 2002; Tatham, 2013; Noferini, 2012). Even in the papers of this special issue we can identify a strategy for many of the case studies such that $\mathrm{CBC}$ is seen as a way out of being trapped in national settings where the border regions are marginalized, by debordering internally in the cross-border regions and therefore territorializing this region. 


\section{Cross-Border Cooperation in Europe: the relational perspective in this special issue}

This special issue aims to combine these three main aspects - network, governance and territorialisation - in relation to different types of cross-border cooperation. In doing so, we follow partly what Graham and Healey (1999) already presented as a need for change in perspective in planning, to 'represent places as multiple layers of relational assets and resources, which generate a distinctive power geometry of places' (p. 642). The multiple networks existing in a cross-border region lead to different and also new forms of crossborder governance with different power relations among the network actors, that then result in 'institutional sites, with particular material geographies' (Healey 2006) and 'relational complexity' (Healey 2006) - in a form of territorialisation of these cross-border networks and governance structures. As this special issue is not discussing formal plans, but more informal cross-border development, the term 'relational perspective', which includes networks, governance and territorialisation, is a key term in this special issue. In this perspective, we combine empirically related concepts as different focal points and argue that it allows one to analyse $\mathrm{CBC}$ in a way that allows one to grasp and understand the dynamics and multiplicity of (informal) planning processes in European border regions. In doing so, we follow Berzi (2017), who identifies (1) a 'flow approach' as an economic approach for marginalized regions, (2) a 'cross-border cooperation approach' with borders as a bridge, (3) a 'territorialist approach' with a focus on the territory, and (4) a 'people approach' focusing on everyday life and identities. Building on Berzi's flows (networks, governance), cross-border cooperation (governance and network) and actors of network (people) and the suggested relational thinking, in a territorialist perspective we will be able to discuss discontinuities as specific challenges as well as opportunities to overcome borders and their separating effects.

Against this background, the articles in this special issue are structured along our three focal 
aspects. Each of the papers deals with all three, but with different priorities - some focusing on one $\mathrm{CBC}$ in-depth, some having a comparative perspective of two or more CBCs. Frątczak-Müller and Mielczarek-Żejmo discuss the significance of cross-border partnerships as social networks based on network construction, network relations and network management to build up common values in the Euroregion Spree-Neisse-Bober, and the role that the Euroregion plays in creating social connections. The authors assume that the Euroregion Spree-Neisse-Bober replaces local institutions by creating cross-border cooperation. The governance as well as the territory where these networks take place are therefore important contexts of the cross-border cooperation.

Andrea Noferini, Matteo Berzi, Francesco Camonita and Antoni Durà combine reterritorialisation processes and multilevel governance in the European Union in analysing and comparing 61 Euroregions throughout Europe and their cross-border cooperation. They conclude that Euroregions 'are neither effective political instruments for re-territorialisation nor new modes of (cross-border) multilevel governance,' but are important for speeding up cross-border cooperation.

The article by Peter Ulrich on territorial cooperation analyses the network structures, the institutional interactions as well as actions of two cross-border networks at the eastern and western German borders through the legal instrument of European Grouping of Territorial Cooperation (EGTC) - the Eurodistrict SaarMoselle, which has already been founded, and the EGTC TransOderana, which is under construction. His analysis shows that networks, governance and to some extent territorialisation can be understood as 'rather post-national approaches' that question the ability of nation-states to support cross-border cooperation.

Pauline Pupier focuses on territorialisation, re-territorialisation as well as deterritorialisation through the institutionalization of cross-border cooperation, by analysing the Cross-Channel Euroregion between France, Belgium and the United Kingdom, and the Upper Rhine region between France, Germany and Switzerland. She points out that cross-border 
regions are very adaptable in defining their perimeters depending on changes in funding, political or other contexts.

Nathalie Christmann, Martine Mostert, Pierre-François Wilmotte, Jean-Marc Lambotte and Mario Cools use the cross-border railway connections between Liège (Belgium) and Maastricht (Netherlands) to show how physical networks can either support or disrupt cross-border connections, as the national perspectives might vary greatly. They also point out that a common cross-border governance would avoid or diminish these different perspectives on developing the cross-border railway, with an impact on social and economic aspects as well as on the labour market.

Besides their relational perspective on networks, governance and territorialisation processes, the articles cover a variety of European cross-border regions, from very small cross-border cooperations (such as EGTC Eurodistrict SaarMoselle) to large ones such as EGTC Cross Channel Euroregion. Some are bilateral, others include more than two states; some are nonformalized entities such as the Lyon-Turin example, or are even legal entities such as the EGTCs. The cross-border cooperations that are analysed also vary in terms of duration of existence, actors involved, financing, content (e.g. transport, social activities), (in)formality of planning processes or management. This variety of case studies provides an excellent basis for testing an overarching relational perspective that allows borders and their separating effects to be overcome, especially in informal cross-border development processes.

\section{Bibliography}

Allmendinger, P., Haughton, G., Knieling, J., Othengrafen F. (eds.) (2015). Soft Spaces in Europe: Re-negotiating Governance: Boundaries and Borders. London - New York:

Routledge. 
Andersen, D.J., Klatt, M., Sandberg, M. (eds.) (2012). The Border Multiple: The Practicing of Borders between Public Policy and Everyday Life in a Re-scaling Europe. Aldershot:

Ashgate.

Association of Border Regions (AEBR) (2018). Cross-border co-operation in Europe.

Retrieved from https://www.aebr.eu/en/members/map_of_members.php

Berzi, M. (2017). The cross-border reterritorialization concept revisited: the territorialist approach applied to the case of Cerdanya on the French-Spanish border. European Planning Studies, 25(9), 1575-1596.

Börzel, T. (2002). States and Regions in the European Union: Institutional Adaptation in Germany and Spain. Cambridge, UK: Cambridge University Press.

Decoville, A., Durand, F. (2016). Building a cross-border territorial strategy between four countries: wishful thinking? European Planning Studies, 24(10), 1825-1843.

Durand, F. (2014). Challenges of Cross-Border Spatial Planning in the Metropolitan Regions of Luxembourg and Lille. Planning, Practice \& Research, 29(2), 113-132.

Eriksen, E.O. (2005). An Emerging European Public Sphere. European Journal of Social Theory, 3, 341-363.

Faludi, A. (2016). The Poverty of Territorialism: Revisiting European Spatial Planning. disP - The Planning Review, 52(3), 73-81.

Fricke, C. (2014). Grenzüberschreitende Governance in der Raumplanung. Organisationsund Kooperationsformen in Basel und Lille. In S. Grotheer, A. Schwöbel, M. Stepper (eds.), Nimm's sportlich - Planung als Hindernislauf (pp. 62-78). Kaiserslautern: ARL. = Arbeitsberichte der ARL 10.

Fricke, C. (2015). Spatial Governance across Borders revisited: Organizational Forms and Spatial Planning in Metropolitan Cross-border Regions. European Planning Studies, 23(5), 849-870. 
Getimis, P. (2012). Comparing Spatial Planning Systems and Planning Cultures in Europe. The Need for a Multi-Scalar Approach. Planning, Practice and Research, 27(1), 25-40. Graham, S. \& Healey, P. (1999). Relational Concepts of Space and Place: Issues for Planning Theory and Practice. European Planning Studies, 7(5), 623-646.

Haughton, G., Allmendinger, P., Counsell, D., Vigar, G. (2010). The New Spatial Planning. Territorial management with soft spaces and fuzzy boundaries. London: Routledge. Healey, P. (2006). Relational Complexity and the Imaginative Power of Strategy Spatial Planning. European Planning Studies, 14(4), 525-546.

Hidle, K. \& Normann, R.H. (2013). Who can govern? Comparing network governance leadership in two Norwegian City regions. European Planning Studies, 21(2), 115-130. Hillgruber, C. (2003). Staats- und völkerrechtliche Aspekte grenzüberschreitender Raumplanung. Hannover: ARL. = ARL-Arbeitsmaterial.

Jacobs, J. (2016). Spatial planning in cross-border regions: A systems-theoretical perspective. Planning Theory, 15(1), 68-90.

Klijn E., Skelcher C. (2007). Democracy and governance networks: compatible or not? Public Administration, 85, 587-608.

Leibenath, M. (2008). Exploring the gaps. Sustainability as a challenge for cross-border governance in Central Europe. In M. Leibenath, E. Korcelli-Olejniczak, R. Knippschild (eds.), Cross-border Governance and Sustainable Spatial Development. Mind the Gaps! (pp. 1-11). Berlin: Springer.

Newman, D. (2011). Contemporary Research Agendas in Border Studies: An Overview. In D. Wastl-Walter, D. (ed.), The Ashgate Research Companion to Border Studies (pp. 33-47). Farnham: Ashgate.

Nienaber, B. (2018). Grenze als überwindbares Phänomen in der Raumplanung? In M. Heintel, R. Musil, N. Weixlbaumer (eds.), Grenzen; Theoretische, konzeptionelle und 
praxisbezogene Fragestellungen zu Grenzen und deren Überschreitungen (pp. 161-179). Wiesbaden: Springer VS.

Noferini, A. (2012). The participation of subnational governments in the Council of the EU: some evidence from Spain. Regional \& Federal Studies, 22(4), 361-385.

Popescu, G. (2008). The conflicting logics of cross-border reterritorialization: Geopolitics of Euroregions in Eastern Europe. Political Geography, 27(4), 418-438.

Schulz, C. (2013). Power Topographies in Cross-Border Spatial Development Policies. In P. Gilles, H. Koff, C. Maganda, C. Schulz (eds.), Theorizing Borders through Analyses of Power Relationships (pp. 111-123). Brussels: Peter Lang.

Scott, J. (2005). Grenzüberschreitende Raumordnung. In ARL (ed.), Handwörterbuch der Raumordnung (pp. 408-414). Hannover: ARL.

Sohn, C. (2014). Modelling cross-border integration: The role of borders as a resource. Geopolitics, 19(3), 587-608.

Tatham, M. (2013). Paradiplomats against the state: Explaining conflict in state and sub-state interest representation in Brussels. Comparative Political Studies, 46(1), 63-94.

Van Houtum, H. (2000). Introduction: Current issues and debates on borders and border regions in European regional science. In: M. Van der Velde, H. Van Houtum (eds.), Border, regions and people (pp. 1-12). London: PION. 